\title{
Implementasi Peraturan Daerah Kabupaten Bungo Nomor 6 Tahun 2015 Tentang Pengelolaan Sampah di Kelurahan Tanjung Gedang Kecamatan Pasar Muara Bungo
}

\author{
Ataka Rama Reta ${ }^{1, *}$, Ikhsan Alfarisi ${ }^{2}$, Joko Susanto ${ }^{3}$ \\ 1, 2, 3 Sekolah Tinggi Ilmu Administrasi Setih Setio Muara Bungo, Jambi, Indonesia \\ ${ }^{1}$ ataka.ramareta@gmail.com, ${ }^{2}$ ikhsan.alfarisi@gmail.com, ${ }^{3}$ jokosusantoo251@gmail.com \\ * corresponding author
}

\begin{tabular}{l} 
A R T I CL E INF O \\
\hline Article history \\
Received 2020-05-01 \\
Revised 2020-06-05 \\
Accepted 2020-06-22 \\
Keywords \\
Implementation, Regional Regulation, \\
Waste, Waste Management, Tanjung \\
Gedang Village
\end{tabular}

\begin{abstract}
Estimated solid waste generated in Bungo District in a day is about 143 tons, and the leading sector in waste management in Bungo Regency is the Office of the Environment, identifying problems in implementing Bungo District Regulation No. 6/2015 on Waste Management in Tanjung Gedang Village, among others: Lack Temporary Shelter, low participation and awareness of the community in maintaining cleanliness, lack of socialization from the government to the community towards the Regional Regulation. The purpose of this study is to examine in depth related to the implementation and inhibiting factors in the implementation of the Regional Regulation in Tanjung Gedang Village. The method used in this research is descriptive method with a qualitative approach. The informants in this study numbered twelve people who were determined by purposive sampling and accidental sampling techniques. The results of this study note that the implementation of Waste Management in Tanjung Gedang Urban Village has not been implemented in accordance with the established regulations, it can be seen from the implementation of rights, obligations, prohibitions, waste management, and sanctions that have not been implemented in accordance with the rules has been established. The inhibiting factors in the implementation of the Regional Regulation are: there is no location and geographically Tanjung Gedang Village is near the riverbanks, making it difficult to create a Temporary Shelter, and there is no waste handling activity. Lack of adequate waste management facilities causes low participation and public awareness in maintaining environmental cleanliness. The limited budget causes a lack of socialization of the Regional Regulation to the public, and there is no firm action from the Government on the enforcement of the norms that have been regulated therein.
\end{abstract}

\section{PENDAHULUAN}

Sampah sudah menjadi suatu keniscayaan dalam kehidupan sehari-hari karena setiap manusia baik individu ataupun kelompok pasti menghasilkan sampah. Begitu juga halnya yang terjadi dalam suatu negara, sampah sekarang telah menjadi permasalahan yang serius kalau tidak dilakukan pengelolaan dengan baik dan benar. Berdasarkan Pasal 1 Angka 1 Undang-Undang Nomor 18 Tahun 2008 Tentang Pengelolaan Sampah, sampah adalah sisa kegiatan sehari-hari manusia dan/atau proses alam yang berbentuk padat. Pengelolaan sampah adalah kegiatan yang sistematis, menyeluruh, dan berkesinambungan yang meliputi perencanaan penanganan dan pengurangan sampah.

Berdasarkan artikel yang ditulis oleh Mareza pada tanggal 07 November 2019 di berita online Tribunjambi.com. Muara Bungo, bahwa di Kabupaten Bungo, sekitar 143 ton sampah dihasilkan setiap harinya. Perkiraan itu dihitung dari jumlah penduduk di Kabupaten Bungo dimana terdiri dari 17 Kecamatan. Kepala Dinas Lingkungan Hidup Kabupaten Bungo, Prasetyo melalui Kepala Bidang 
(Kabid) Kebersihan, Zulkarnain memperkirakan atau memprediksikan, setiap orang di Kabupaten Bungo membuang sampah sekitar 0,4 kilogram (Kg) setiap harinya. Dengan jumlah penduduk 357.860 jiwa, diperkirakan atau diprediksikan total sampah yang ditimbun setiap harinya sekitar 143 ton. Estimasinya, setiap orang membuang sampah sekitar 0,4 kilogram $(\mathrm{Kg})$ per harinya, dikalikan jumlah penduduk sebanyak 357.860 jiwa. Maka totalnya sekitar 143 ton per hari. 'Dirincikannya, produksi sampah terbanyak terjadi di sekitaran Kota Muara Bungo,sekitar 75 ton. Jumlah tersebut merupakan sampah yang terkumpul dari empat kecamatan, yaitu Pasar Muara Bungo, Rimbo Tengah, Bungo Dani, dan Bathin III.

Leading sector dalam pengelolaan persampahan di Kabupaten Bungo adalah Dinas Lingkungan Hidup (DLH) yang seharusnya lebih aktif dalam penanganan sampah dan pengurangan sampah seiring dengan bertambahnya jumlah penduduk di Kabupaten Bungo setiap tahunnya, juga berakibat terhadap naiknya jumlah rata-rata produksi sampah. Adapun pengelolaan sampah di Kabupuaten Bungo sendiri meliputi: Pertama, Pemilahan, kegiatan pemilihan sampah dilakukan dalam bentuk pengelompokan dan pemisahan sampah sesuai dengan jenis, jumlah dan sifat sampah, pemilahan dilakukan oleh masyarakat ataupun pemerintah daerah. Kedua, pengumpulan, pengumpulan sampah dilakukan dalam bentuk pengambilan dan memindahkan sampah dari sumber sampah seperti sampah rumah tangga ke Tempat Penampungan Sementara (TPS). Ketiga, pengangkutan, pengangkutan sampah dilakukan dalam bentuk membawa sampah dari sumber sampah yang ada di masyarakat dan dari tempat penampungan sementara menuju ke TPA (Tempat Pemprosesan Akhir). Keempat, pengolahan, sampah yang didapatkan tersebut diolah dengan cara pemadatan, pengomposan dan daur ulang. Kelima, pemprosesan akhir sampah, dilakukan dalam bentuk pengembalian sampah ke media lingkungan secara aman.

Persoalan sampah di Kabupaten Bungo tidak boleh dianggap sepele atau hanya dipandang sebelah mata, khususnya masalah sampah yang ada di Kelurahan Tanjung Gedang, Kecamatan Pasar Muara Bungo, Kabupaten Bungo, masalah sampah haruslah dikelola dengan baik, karena jika sampah yang tidak dikelola dengan baik maka dapat mengakibatkan lingkungan menjadi kotor dan menyebabkan pendangkalan sungai yang mengakibatkan datangnya banjir. Selain itu, sampah dapat mengakibatkan meningkatnya penyebaran penyakit, bau menyengat sehingga mengganggu kenyamanan dan kesehatan masyarakat. Pengelolaan sampah harus dilakukan secara integral agar dapat memberikan manfaat secara ekonomi, sehat bagi masyarakat, aman bagi lingkungan, dan dapat mengubah perilaku masyarakat, harapan akan terwujudnya kebersihan lingkungan, setiap masyarakat harus ikut berpartisipasi didalamnya menyikapi hal tersebut Pemerintah Kabupaten Bungo mengeluarkan Peraturan Daerah Nomor 6 Tahun 2015 Tentang Pengelolaan Sampah.

Implementasi Peraturan Daerah Nomor 6 Tahun 2015 Tentang Pengelolaan Sampah di Kelurahan Tanjung Gedang Kecamatan Pasar Muara Bungo secara implementatif belum sesuai dengan aturan yang telah ditetapkan. Berdasarkan Pasal 16 Peraturan Daerah Kabupaten Bungo Nomor 6 tahun 2015 Tentang Pengelolaan Sampah, yang menyatakan bahwa setiap penduduk atau pemilik/penghuni bangunan dilarang sebagai berikut :

a. Membuang sampah atau yang dianggap sampah ke dalam sungai, bantaran sungai, got, saluran air, saluaran-saluran air, gang-gang, taman, lapangan, serta tempat-tempat umum lainnya;

b. Membakar sampah di jalan, jalur hijau, taman dan tempat umum disekitar perkarangan sehingga mengganggu ketertiban umum;

c. Menutup selokan di sekitar perkarangan yang dapat menghambat pembersihan sampah, tanpa izin Bupati;

d. Membuang air besar (hajat besar) dan buang air kecil (hajat kecil) di jalan, jalur hijau, taman saluran dan tempat umum kecuali tempat-tempat yang telah ditentukan instansi pelaksana;

e. Membuang sampah di luar lokasi yang telah ditetapkan;

f. Membuang barang-barang atau kotoran yang dikategorikan sebagai sampah spesifik seperti benda tajam, pecahan kaca, batang-batang pohon, benda-benda berbau seperti bangkai hewan, rambatan pagar halaman, serta bongkahan bangunan harus dimusnahkan sendiri atau dapat meminta bantuan Dinas/Instansi terkait dengan pelayanan khusus;

g. Membuang sampah di tempat penampungan sampah sementara di luar jam-jam yang telah ditetapkan untuk itu. 
Dari norma-norma yang telah diatur di atas, permasalahan yang terjadi di lapangan masih banyak ditemukan masyarakat yang melanggar dan tidak mematuhi norma-norma yang telah ditetapkan di dalam Peraturan Daerah Kabupaten Bungo Nomor 6. Tahun 2015 Tentang Pengelolaan Sampah, khususnya di Kelurahan Tanjung Gedang.

Berdasarkan uraian di atas, maka peneliti tertarik untuk melakukan penelitian ini yakni terkait implementasi Peraturan Darerah Kabupaten Bungo Nomor 6 Tahun 2015 Tentang Pengelolaan Sampah di Kelurahan Tanjung Gedang, Kecamatan Pasar Muara Bungo, maka dari itu peneliti merumuskan pertanyaan penelitian yaitu bagaimana implemenetasi dan apa faktor-faktor penghambat implementasi Peraturan Daerah Kabupaten Bungo Nomor 6 Tahun 2015 tentang Pengelolaan Sampah di Kelurahan Tanjung Gedang, Kecamatan Pasar Muara Bungo? Oleh karena itu perlu dilakukan penelitian ini untuk dapat menjelaskan dan memberikan informasi mengenai permasalahan yang ada sehingga dapat diambil solusi agar pelaksanaan atau penerapan Peraturan Daerah tersebut sesuai dengan aturan-aturan yang telah ditetapkan. Tujuan dilakukan penelitian ini adalah untuk mengkaji secara mendalam terkait implementasi Peraturan Daerah tersebut di Kelurahan Tanjung Gedang, Kecamatan Pasar Muara Bungo, Kabupaten Bungo, sehingga dapat memberikan rekomendasi agar pelaksanaan atau penerapan Peraturan Daerah tersebut sesuai dengan aturan-aturan yang telah ditetapkan agar dapat terwujudnya lingkungan yang sehat dan bersih dari sampah.

\section{KAJIAN PUSTAKA}

\section{Kebijakan Publik}

Pengertian kebijakan publik menurut Thomas R Dye (2008:1), mengemukakan: "public policy is what ever governments choose to do or not to do", konsep ini menjelaskan bahwa kebijakan publik ialah "apapun yang dipilih oleh pemerintah untuk dilakukan atau tidak dilakukan". Menurutnya bahwa bilamana pemerintah memilih untuk melakukan sesuatu maka harus ada tujuan dan kebijakan negara tersebut harus meliputi semua tindakan pemerintah, bukan semata-mata pernyataan keinginan pemerintah atau pejabatnya. Di samping itu sesuatu yang tidak dilaksanaakan oleh pemerintah pun termasuk kebijakan negara. Hal ini disebabkan "sesuatu yang tidak dilakukan" oleh pemerintah akan mempunyai pengaruh yang sama besarnya dengan "sesuatu yang dilakukan oleh pemerintah".

\section{Implementasi Kebijakan Publik}

Menurut Budi Winarno (2014:146-147) dalam bukunya yang berjudul Kebijakan Publik menyatakan bahwa implementasi kebijakan ialah tahap yang krusial atau penting dalam proses kebijakan publik. Suatu program kebijakan harus diimplementasikan atau dilaksanakan agar dapat mempunyai tujuan atau dampak yang diinginkan atau yang diharapkan. Implementasi kebijakan dilihat dalam pengertian yang luas, ialah tahap dari proses kebijakan segera setelah penetapan Undang-Undang. Implementasi dilihat secara luas mempunyai makna atau maksud pelaksanaan Undang-Undang di mana berbagai aktor, organisasi, prosedur, dan teknik bekerja bersama-sama untuk menjalankan kebijakan dalam upaya untuk meraih atau mendapatkan tujuan-tujuan kebijakan atau program-program.

Model implementasi kebijakan menurut Devid L. Weimer dan Aidan R. Vining dalam Arifin Tahir (2015:76) yang mengemukakan ada tiga kelompok variabel besar yang dapat mempengaruhi keberhasilan implementasi suatu program yakni: ..Pertama, logika kebijakan. Kedua, lingkungan tempat kebijakan dioperasionalkan. Ketiga, kemampuan implementor kebijakan.

1. Logika dari suatu kebijakan ini dimaksudkan agar suatu kebijakan yang diterapkan masuk akal (reasonable) dan mendapat dukungan teoritis.

2. Lingkungan tempat kebijakan tersebut dioperasikan akan mempengaruhi keberhasilan implementasi suatu kebijakan.

3. Kemampuan implementor suatu kebijakan dapat dipengaruhi oleh tingkat kompetensi dan keterampilan dari para implementor kebijakan.

\section{Pengelolaan Sampah}

Berdasarkan Pasal 1 Angka 4 Peraturan Daerah Kabupaten Bungo Nomor 6 Tahun 2015 tentang pengelolaan sampah yang menyatakan: Sampah adalah sisa kegiatan sehari-hari manusia dan/atau 
proses alam yang berbentuk padat yang terdiri atas sampah rumah tangga maupun sampah sejenis sampah rumah tangga.

Berdasarkan Pasal 1 Angka 5 Undang-Undang Nomor 18 Tahun 2008 Tentang Pengelolaan Sampah yang menyatakan: Pengelolaan sampah adalah kegiatan yang sistematis, menyeluruh, dan berkesinambungan yang meliputi pengurangan dan penanganan sampah.

Berdasarkan Pasal 20 Ayat (1) Undang-Undang Nomor 18 Tahun 2008 Tentang Pengelolaan Sampah yang menyatakan pengurangan sampah sebagaimana dimaksud dalam Pasal 19 Huruf a meliputi :

a. Pembatasan timbulan sampah;

b. Pendauran ulang sampah dan/atau

c. Pemanfaatan kembali sampah.

Selanjutnya Berdasarkan Pasal 22 Ayat (1) Undang-Undang Nomor 18 Tahun 2008 Tentang Pengelolaan Sampah yang menyatakan bahwa kegiatan penanganan sampah sebagaimana dimaksud dalam Pasal 19 Hurup b meliputi:

a. Pemilahan dalam bentuk pengelompokan dan pemisahan sampah sesuai dengan jenis, jumlah dan sifat sampah,

b. Pengumpulan dalam bentuk pengambilan dan pemindahan sampah dari sumber sampah ke tempat penampungan sementara atau tempat pengolahan sampah terpadu,

c. Pengangkutan dalam bentuk membawa sampah dari sumber atau dari tempat penampungan sampah sementara atau dari tempat pengolahan sampah terpadu menuju ke tempat pemrosesan akhir,

d. Pengolahan dalam bentuk mengubah karakteristik, komposisi, dan jumlah sampah,

e. Pemrosesan akhir sampah dalam bentuk pengembalian sampah atau residu hasil pengolahan sebelumnya ke media lingkungan secara aman.

\section{Metode Pengelolaan Sampah}

Menurut Wied Harry Apriadji (2005:8-11) tentang cara-cara pembuangan sampah (refuse disposal) atau tahap pemusnahan sampah di antaranya:

1. Penimbunan tanah (Land fill)

Sampah yang telah terkumpul bertruk-truk dari pasar dan rumah tangga dimanfaatkan untuk menimbun tanah rendah. Tanah ditimbun begitu saja sampai menggunung. Lalu diratakan dan dipadatkan. Setelah ketinggian permukaan mencapai yang diinginkan.

2. Penimbunan tanah secara sehat (Sanitary land fill)

caranya sampah dibuang dan dibiarkan menggunung seperti cara land fill di atas. Tetapi, setelah sampah mencapai ketinggian yang diinginkan, permukaan atasnya segera di timbun tanah. Lapisan tanah ini sedikitnya harus setebal $60 \mathrm{~cm}$.

3. Pembakaran sampah (Incineration)

Membakar sampah yang sudah terkumpul seperti sudah menjadi kebiasaan bagi masyarakat kebanyakan di pinggiran kota dan di daerah pedesaan.

4. Penghancuran (Pulverisation)

Sampah yang berasal dari bak-bak penampung langsung dihancurkan dan dileburkan menjadi potongan-potongan kecil sehingga lebih ringkas. Sampah lumat ini selain dimanfaatkan untuk menimbun tanah rendah juga bisa dibuang ke laut tanpa menimbulkan pencemaran.

5. Pengomposan (Composting)

Telah banyak lembaga usaha swasta yang memanfaatkan buangan sampah untuk dibuat pupuk kompos dan kemudian dipasarkan secara komersial.

6. Makanan ternak (Hogfeeding)

Sampah jenis garbage, seperti sisa sayuran, ampas tapioca, ampas tahu, bisa dimanfaatkan sebagai makanan ternak. Dari pada sampah-sampah itu dibuang percuma.

7. Pemanfaatan ulang (Recycling)

Sampah-sampah yang sekiranya masih dapat atau bisa diolah kembali, dikumpulkan dan dipungut. Contohnya adalah kertas-kertas, pecahan kaca, botol bekas, logam-logam, potongan plastik, dan 
sebagainya. Sehingga dari sampah semacam ini akan dibuat kembali kardus pembukus, alat-alat perangkat rumah tangga dari plastik dan kaca.

\section{METODE PENELITIAN}

Penelitian ini merupakan penelitian deskriptif dengan pendekatan kualitatif. Dalam penelitian ini peneliti mengambil informan dengan menggunakan teknik purposive sampling dan accidental sampling. Purposive sampling adalah teknik penentuan sampel dengan pertimbangan tertentu. Sedangkan accidental sampling adalah teknik penentuan sampel berdasarkan kebetulan, yaitu siapa saja yang secara kebetulan/asidental bertemu peneliti dapat digunakan sebagai sampel, bila dipandang orang yang kebetulan ditemui cocok sebagai sumber data. Adapun yang menjadi informan dalam penelitian ini berjumlah 12 (dua belas) orang yaitu terdiri dari 2 (dua) informan dari pihak Dinas Lingkungan Hidup Kabupaten Bungo, 2 (dua) informan dari pihak kantor Kelurahan Tanjung Gedang dan 8 (delapan) informan dari pihak masyarakat Kelurahan Tanjung Gedang. Teknik pengumpulan data dalam penelitian ini yaitu penelitian kepustakaan (library research) yaitu memanfaatkan perpustakaan sebagai sarana dalam mengumpulkan data, dengan mempelajari buku-buku, peraturan-peraturan sebagai bahan referensi yang berhubungan dengan penelitian ini dan studi lapangan (field research), studi lapangan merupakan suatu cara yang dilakukan dan digunakan untuk mengumpulkan data primer melelalui observasi, wawancara dan dokumentasi.

Wawacara ini diupayakan untuk mendapatkan data sebanyak mungkin dari para informan terkait dengan pengelolaan sampah yang dilaksanakan sehingga data-data yang muncul adalah pernyataanpernyataan yang dikemukan oleh para informan mengenai implementasi Peraturan Daerah tentang pengelolaan sampah di Kelurahan Tanjung Gedang, Kecamatan Pasar Muara Bungo. Selanjutnya dalam penelitian ini, peneliti melakukan obsevasi di lokasi dengan pemilihan secara purposive dibeberapa tempat. Selanjutnya data yang dapat dikumpulkan melalui metode dokumentasi ini data adalah data gambar masyarakat yang masih sering membuang sampah di sembarangan tempat dan data tentang Dinas Lingkungan Hidup dan data tentang Kelurahan serta masyarakat di Kelurahan Tanjung Gedang, Kecamatan Pasar Muara Bungo. Teknik analisis data dalam penelitian ini menggunakan model interaktif Miles dan Huberman yang dimulai dengan Pengumpulan Data, Data dikumpulkan dari sumber data primer dan sekunder, dengan observasi, wawancara, dan dokumentasi. Selanjutnya reduksi data yaitu mereduksi/menyotir data dengan cara memilih hal-hal yang pokok, memfokuskan pada hal-hal yang penting dan dicari tema serta polanya. Selanjunya penyajian data, penyajian data dilakukan dalam bentuk uraian singkat, bagan, hubungan antar kategori serta dalam bentuk teks yang bersifat naratif dan terakhir yaitu Penarikan Kesimpulan/Verifikasi yang merupakan temuan baru yang sebelumnya belum pernah ada. Sehingga kesimpulan dalam penelitian ini merupakan jawaban terhadap rumusan masalah yang dirumuskan sejak awal. Temuan berupa deskripsi atau gambaran suatu objek.

\section{HASIL DAN PEMBAHASAN}

\section{Implementasi Peraturan Daerah Kabupaten Bungo Nomor 6 Tahun 2015 Tentang Pengelolaan Sampah di Kelurahan Tanjung Gedang Kecamatan Pasar Muara Bungo.}

Untuk melihat implementasi kebijakan berjalan dengan optimal atau tidak, di sini peneliti melihat kesesuaian antara aturan-aturan yang telah ditetapkan di dalam Peraturan Daerah Kabupaten Bungo Nomor 6 Tahun 2015 Tentang Pengelolaan Sampah, dengan yang terjadi di lapangan, dalam hal ini pelaksanaan atau penerapan Peraturan daerah tersebut di Kelurahan Tanjung Gedang, aturan-aturan yang dimaksud ialah hak, kewajiban, larangan, penanganan sampah, ketentuan sanksi, sebagai berikut :

1. Hak

Berdasarkan Pasal 7 Peraturan Daerah Kabupaten Bungo Nomor 6 Tahun 2015 tentang Pengelolaan Sampah, yang menyatakan bahwa setiap orang berhak untuk mendapatkan pelayanan, berpartisipasi, memperoleh informasi, mendapatkan perlindungan dan kompensasi, dan meemperoleh pembinaan dalam pengelolaan sampah.

Berdasarkan hasil penelitian tentang pelaksanaan ketentuan hak yang didapatkan masyarakat di Kelurahan Tanjung Gedang belum dilaksanakan sesuai dengan aturan-aturan yang telah ditetapkan 
dikarenakan masih banyak masyarakat yang belum mendapatkan haknya sebagaimana yang telah diatur di dalam Peraturan Daerah tersebut.

2. Kewajiban

Berdasarkan Pasal 8 Peraturan Daerah Kabupaten Bungo Nomor 6 Tahun 2015 tentang Pengelolaan Sampah, yang menyatakan bahwa setiap orang berkewajiban untuk memelihara kebersihan, menyediakan tempat-tempat sampah dan tempat sampah tersebut difasilitasi oleh pemerintah daerah, Camat dan Lurah bertanggung jawab terhadap pelaksanaan pengelolaan sampah mulai dari sumber sampah/dari rumah-rumah masyarakat sampai ke TPS.

Berdasarkan hasil penelitian tentang pelaksanaan ketentuan kewajiban yang diwajibkan bagi masyarakat dan pemerintah di Kelurahan Tanjung Gedang belum dilaksanakan sesuai dengan aturan-aturan yang telah ditetapkan dikarenakan Lurah Tanjung Gedang tidak menyadari bahwasanya Lurah bertanggung jawab terhadap pelaksanaan pengelolaan sampah di Kelurahan dan belum adanya fasilitasi dari pemerintah dalam hal ini pengangkutan sampah dari rumah masyarakat.

3. Larangan

Berdasarkan Pasal 16 Peraturan Daerah Kabupaten Bungo Nomor 6 Tahun 2015 tentang Pengelolaan Sampah, yang menyatakan bahwa setiap penduduk/pemilik/penghuni bangunan dilarang membuang sampah atau yang dianggap sampah ke sungai, bantaran sungai, got, saluran air, gang-gang, taman, lapangan dan tempat umum lainya. Dilarang membakar sampah di jalan, jalur hijau, taman dan tempat umum di sekitar perkarangan masing-masing sehingga menganggu ketertiban umum, membuang sampah di luar lokasi yang telah ditetapkan, dan diluar jam-jam yang telah ditetapkan.

Berdasarkan hasil penelitian tentang pelaksanaan ketentuan larangan bagi masyarakat di Kelurahan Tanjung Gedang belum dilaksanakan sesuai dengan aturan-aturan yang telah ditetapkan dikarenakan masih banyak masyarakat masih banyak yang melanggar dan tidak mematuhi aturanaturan tersebut seperti membuang sampah ke sungai, bantaran sungai, got, tanah kosong dan membakar sampah yang menyebabkan terganggunya ketertinban umum.

\section{Penanganan Sampah}

a. Pemilahan

Berdasarkan Pasal 20 Peraturan Daerah Kabupaten Bungo Nomor 6 Tahun 2015 tentang Pengelolaan Sampah, yang menyatakan bahwa pemilahan adalah kegiatan yang dilakukan dalam bentuk pengelompokan dan pemisahan sampah sesuai dengan jenis jumlah dan/atau sifat sampah. Sarana pemilahan disediakan oleh pengelola kawasan dan pemerintah daerah yang mana harus memenuhi persyaratan jumlah sarana sesuai dengan jenis pengelompokan sampah diberi symbol, tanda, bentuk dan warna wadah.

Berdasarkan hasil penelitian tentang pelaksanaan ketentuan mengenai kegiatan pemilahan di Kelurahan Tanjung Gedang belum dilaksanakan sesuai dengan aturan-aturan yang telah ditetapkan dikarenakan kegitan pemilahan tersebut hanya dilakukan oleh sebagian kecil masyarakat dan masih besandar kepada masyarakat itu sendiri karena belum adanya kerja sama dari semua pihak baik itu pemerintah, masyarakat dan swasta. Selanjutnya sarana pemilahan belum disediakan oleh pengelola kawasan ataupun dari pemerintah daerah.

b. Pengumpulan

Berdasarkan Pasal 21 Peraturan Daerah Kabupaten Bungo Nomor 6 Tahun 2015 tentang Pengelolaan Sampah, yang menyatakan bahwa pengumpulam adalah kegiatan yang dilakukan dalam bentuk pengambilan dan pemindahan sampah dari sumber sampah ke Tempat Penampungan Sementara (TPS) atau Tempat Pengelolaan Sampah Terpadu (TPST) TPA. SKPD yang membidangi persampahan dan lingkungan hidup menyediakan TPS/TPS3R yang harus memenuhi persyaratan yaitu Tersedianya sarana pengelompokan minimal 5 jenis, luas lokasi dan kapasitas sesuai kebutuhan, lokasi yang mudah diakses, tidak mencemari lingkungan dan memiliki jadual pengumpulan dan pengangkutan. 
Berdasarkan hasil penelitian tentang pelaksanaan ketentuan mengenai kegiatan pengumpulan di Kelurahan Tanjung Gedang belum dilaksanakan sesuai dengan aturan-aturan yang telah ditetapkan dikarenakan ketidaktahuan bahwasanya Kelurahan Tanjung Gedang telah memiliki TPS sehingga tidak adanya kegiatan pengumpulan sampah tersebut.

c. Pengangkutan

Berdasarkan Pasal 22 dan 23 Peraturan Daerah Kabupaten Bungo Nomor 6 Tahun 2015 tentang Pengelolaan Sampah, yang menyatakan bahwa pengangkutan adalah kegiatan yang dilakukan dalam bentuk membawa sampah dari sumber dan/atau dari TPS atau dari TPST menuju ke Tempat Pemprosesan Akhir (TPA), pengangkutan sampah dilakukan oleh pemerintah daerah dengan menyediakan alat angkut sampah terpilah paling sedikit 5 jenis sampah dan pembuangan tidak mencemari lingkungan.

Berdasarkan hasil penelitian tentang pelaksanaan ketentuan mengenai kegiatan pengangkutan di Kelurahan Tanjung Gedang belum dilaksanakan sesuai dengan aturan-aturan yang telah ditetapkan dikarenakan saat ini pengangkutan sampah dari rumah-rumah masyarakat belum dilakukan.

d. Pengolahan

Berdasarkan Pasal 24 Peraturan Daerah Kabupaten Bungo Nomor 6 Tahun 2015 tentang Pengelolaan Sampah, yang menyatakan bahwa pengolahan adalah kegiatan yang meliputi: Pemadatan, pengomposan dan daur ulang. Pengelola kawasan dan pemerintah daerah dalam melakukan pengolahan wajib menyediakan TPS $3 \mathrm{R}$ pada wilayah permukiman.

Berdasarkan hasil penelitian tentang pelaksanaan ketentuan mengenai kegiatan pengolahan di Kelurahan Tanjung Gedang belum dilaksanakan sesuai dengan aturan-aturan yang telah ditetapkan dikarenakan Kelurahan Tanjung Gedang belum memilki TPS 3R sehingga kegiatan pengolahan tersebut belum dilaksanakan.

e. Pemprosesan akhir sampah

Berdasarkan Pasal 25 Peraturan Daerah Kabupaten Bungo Nomor 6 Tahun 2015 tentang Pengelolaan Sampah, yang menyatakan bahwa pemprosesan akhir sampah adalah kegiatan yang dilakukan dalam bentuk pengembalian sampah dan/atau residu hasil pengolahan sebelumnya ke media lingkungan secara aman dan kegiatan pemprosesan akhir sampah dilakukan oleh pemerintah daerah.

Berdasarkan hasil penelitian tentang pelaksanaan ketentuan mengenai kegiatan pemprosesan akhir sampah di TPA belum dilaksanakan sesuai dengan aturan-aturan yang telah ditetapkan dikarenakan yang terjadi di lapangan yaitu di Tempat Pemprosesaan Akhir (TPA) yang mana dalam kegiatan pemprosesan akhir sampah masih ditemukan bahwa bukan hanya sampah residu/sampah yang yang tidak dapat dimanfaatkan lagi yang ditimbun, namun juga sampah yang masih dapat dimanfaatkan juga ditimbun, seharusnya sampah yang dapat dimanfaatkan tersebut tidak ditimbun, tetapi diolah sesuai dengan jenis dan sifat sampah baik dijadikan kompos ataupun didaur ulang sehingga dapat menjadi sumber daya yang memiliki nilai ekonomis dan dapat memperpanjang umur Tempat Pemprosesan Akhir (TPA).

\section{Ketentuan Sanksi}

Berdasarkan Pasal 33 Peraturan Daerah Kabupaten Bungo Nomor 6 Tahun 2015 tentang Pengelolaan Sampah, yang menyatakan bahwa ketentuan sanksi pidana apabila pasal-pasal yang tertuang dalam Peraturan Daerah tersebuat dilanggar adapun sanksi tersebuat ialah dipidana dengan pidana kurungan paling lama 6 bulan dan/atau denda paling banyak RP. 50.000.000,- (limah puluh juta rupiah).

Berdasarkan hasil penelitian tentang pelaksanaan ketentuan sanksi bagi pelanggar di Kelurahan Tanjung Gedang belum dilaksanakan sesuai dengan aturan-aturan yang telah ditetapkan dikarenakan banyak masyarakat yang melanggar pasal-pasal di dalam ketentuan sanksi tersebut, namun tidak diberi sanksi sabagaimana mestinya. 


\section{Faktor-faktor Penghambat Implementasi Peraturan Daerah Kabupaten Bungo Nomor 6 Tahun 2015 Tentang Pengelolaan Sampah di Kelurahan Tanjung Gedang Kecamatan Pasar Muara Bungo}

Berdasarkan hasil penelitian terhadap implementasi Peraturan Daerah Kabupaten Bungo Nomor 6 Tahun 2015 Tentang Pengelolaan Sampah di Kelurahan Tanjung Gedang Kecamatan Pasar Muara Bungo untuk terwujudkan lingkungan yang sehat dan bersih dari sampah, namun juga diakui dalam pelaksanaannya belum sesuai dengan aturan-aturan yang telah ditetapakan dalam Peraturan Daerah tersebut, sehingga peneliti mengkaji faktor-faktor yang menghambat implementasi Peraturan Daerah Kabupaten Bungo Nomor 6 Tahun 2015 Tentang Pengelolaan Sampah di Kelurahan Tanjung Gedang Kecamatan Pasar Muara Bungo, diantaranya :

1. Belum adanya lokasi dan secara geografis Kelurahan Tanjung Gedang berada di dekat bantaran sungai, sehingga sulit untuk dibuat/diletakan Tempat Penampungan Sementara (TPS), serta belum adanya kegiatan penanganan sampah yaitu pemilahan pengumpulan dan pengangkutan.

Berdasarkan hasil penelitian di Kelurahan Tanjung Gedang bahwa faktor penghambat dalam implementasi Peraturan Daerah Kabupaten Bungo Nomor 6 Tahun 2015 Tentang Pengelolaan Sampah di Kelurahan Tanjung Gedang Kecamatan Pasar Muara Bungo, tehadap kurangnya Tempat Penampungan Sementara (TPS) yaitu dikarenakan tidak mempunyai lokasi atau tanah, untuk dibangun/diletakkan Tempat Penampungan Sementara (TPS), dan Kelurahan Tanjung Gedang merupakan daerah rawan banjir, selanjutnya terkait belum adanya kegiatan penanganan sampah berupa pemilahan, pengumpulan dan pengangkutan, yaitu: Pemilahan disebabkan belum adanya sarana pemilahan sampah yang disediakan oleh Pemerintah Daerah. Pengumpulan disebabkan ketidaktahuan masyarakat bahwa di Kelurahan Tanjung Gedang telah memiliki Tempat Penampungan Sementara (TPS). Pengangkutan disebabkan belum adanya kerjasama antara Dinas Lingkungan Hidup dengan pihak Kelurahan ataupun dengan masyarakat Kelurahan Tanjung Gedang.

2. Kurangnya sarana pengelolaan sampah yang memadai di Kelurahan Tanjung Gedang yang menjadi penyebab rendahnya partisipasi dan kesadaran masyarakat dalam menjaga kebersihan lingkungan

Berdasarkan hasil penelitian di Kelurahan Tanjung Gedang bahwa faktor penghambat dalam implementasi Peraturan Daerah Kabupaten Bungo Nomor 6 Tahun 2015 Tentang Pengelolaan Sampah di Kelurahan Tanjung Gedang Kecamatan Pasar Muara Bungo, terhadap rendahnya partisipasi dan kesadaran masyarakat dalam menjaga kebersihan lingkungan disebabkan oleh kurangnya sarana pengelolaan sampah seperti kurangnya Tempat Penampungan Sementara (TPS) dan tidak adanya kegiatan pengangkutan, sehingga mengakibatkan banyaknya masyarakat yang membuang sampah sembarangan, bahkan membuang sampah ke sungai Batang Bungo, bantaran sungai, di tanah kosong sehingga terjadi penumpukan sampah di beberapa tempat, yang menimbulkan bau busuk, dan meningkatkan penyebaran penyakit bagi masyarakat.

3. Keterbatasan anggaran menyebabkan kurangnya sosialisasi tehadap Peraturan Daerah Kabupaten Bungo Nomor 6 Tahun 2015 Tentang Pengelolaan Sampah kepada masyarakat di Kelurahan Tanjung Gedang, serta belum adanya tindakan tegas dari Pemerintah terhadap penegakan norma-norma yang diatur di dalam Peraturan Daerah tersebut.

Berdasarkan hasil penelitian di Kelurahan Tanjung Gedang bahwa faktor penghambat dalam implementasi Peraturan Daerah Kabupaten Bungo Nomor 6 Tahun 2015 Tentang Pengelolaan Sampah di Kelurahan Tanjung Gedang Kecamatan Pasar Muara Bungo, tehadap kurangnya sosialisasi tehadap Peraturan Daerah Kabupaten Bungo Nomor 6 Tahun 2015 Tentang Pengelolaan Sampah kepada masyarakat disebabkan oleh keterbatasan anggaran sehingga sosialisasi yang dilakukan tidak maksimal dan belum menjangkau masyarakat Kabupaten Bungo secara keseluruhan sehingga masih banyak masyarakat yang tidak tahu dengan adanya Peraturan daerah tersebut dengan segala ketentuan-ketentuan yang diatur di dalamnya.

Selanjutnya mengenai belum adanya tindakan dari pemerintah terhadap penegakan normanorma yang diatur di dalam Peraturan Daerah tersebut disebabkan oleh Satuan Polisi Pamong Praja belum melaksanakan tugas pokok dan fungsinya sebagai pihak yang berwenang menegakan norma- 
norma Peraturan Daerah sehingga mengakibatkan banyak masyarakat yang tidak mematuhi serta melanggar ketentuan-ketentuan yang diatur di dalam Peraturan Daerah tersebut.

\section{KESIMPULAN DAN SARAN}

Berdasarkan hasil penelitian dan pembahasan dapat disimpulkan bahwa :

1. Implementasi Peraturan Daerah Kabupaten Bungo Nomor 6 Tahun 2015 Tentang Pengelolaan Sampah di Kelurahan Tanjung Gedang Kecamatan Pasar Muara Bungo, secara implementatif belum berjalan sesuai dengan aturan-aturan yang telah ditetapkan, hal ini terlihat dari implementasi ketentuan-ketentuan hak, kewajiban, larangan, penanganan sampah, dan ketentuan sanksi di Kelurahan Tanjung Gedang yang belum dilaksanakan atau diterapkan sesuai dengan aturan-aturan yang telah ditetapkan.

2. Faktor-faktor penghambat implementasi Peraturan Daerah Kabupaten Bungo Nomor 6 Tahun 2015 Tentang Pengelolaan Sampah di Kelurahan Tanjung Gedang Kecamatan Pasar Muara Bungo, diantaranya :

a. Belum adanya lokasi dan secara geografis Kelurahan Tanjung Gedang berada di dekat bantaran sungai, sehingga sulit untuk dibuat/diletakkan Tempat Penampungan Sementara (TPS), serta belum adanya kegiatan penanganan sampah yaitu pemilahan, pengumpulan, dan pengangkutan.

b. Kurangnya sarana pengelolaan sampah yang memadai di Kelurahan Tanjung Gedang yang menjadi penyebab rendahnya partisipasi dan kesadaran masyarakat dalam menjaga kebersihan lingkungan.

c. Keterbatasan anggaran menyebabkan kurangnya sosialisasi tehadap Peraturan Daerah Kabupaten Bungo Nomor 6 Tahun 2015 Tentang Pengelolaan Sampah kepada masyarakat di Kelurahan Tanjung Gedang, serta belum adanya tindakan tegas dari Pemerintah terhadap penegakan normanorma yang diatur di dalam Peraturan Daerah tersebut.

Berdasarkan hasil penelitian mengenai implementasi Peraturan Daerah Kabupaten Bungo Nomor 6 Tahun 2015 tentang Pengelolaan Sampah di Kelurahan Tanjung Gedang Kecamatan Pasar Muara Bungo Kabupaten Bungo belum berjalan sesuai dengan ketentuan yang telah ditetapkan, maka perlu adanya perbaikan sehingga kedepannya kebijakan pengelolaan sampah ini dapat mencapai tujuan yaitu terwujudnya lingkungan yang bersih dan sehat dari sampah. Oleh karena itu peneliti memberikan saransaran berdasarkan temuan di lapangan, yaitu:

1. Diharapkan kepada Dinas Lingkungan Hidup Kabupaten Bungo dan Kelurahan Tanjung Gedang untuk segera menyediakan sarana Tempat Penampungan Sementara (TPS) yang memenuhi persyaratan sesuai dengan yang di ataur di dalam Peratauran Daerah Kabupaten Bungo Nomor 6 Tahun 2015 Tentang Pengelolaan Sampah ataupun mensosialisasikan Tempat Penampungan Sementara (TPS) yang ada.

2. Diharapkan kepada Dinas Lingkungan Hidup Kabupaten Bungo untuk segera melaksanakan kegiatan penanganan sampah berupa pemilahan, pengumpulan, dan pengangkutan di Kelurahan Tanjung Gedang, Kecamatan Pasar Muara Bungo.

3. Diharapkan kepada Dinas Lingkungan Hidup Kabupaten Bungo dan Kelurahan Tanjung Gedang untuk meningkatkan partisipasi dan kesadaran masyarakat terhadap kebersihan lingkungan khususnya di Kelurahan Tanjung Gedang Kecamatan Pasar Muara Bungo.

4. Diharapkan kepada Dinas Lingkungan Hidup Kabupaten Bungo dan Kelurahan Tanjung Gedang meningkatkan sosialisasi teradap Peraturan Daerah Kabupaten Bungo Nomor 6 Tahun 2015 Tentang Pengelolaan Sampah kepada masyarakat khususnya di kelurahan Tanjung Gedang.

5. Diharapkan kepada Pemerintah Daerah mengikut sertakan Satuan Polisi Pamong Praja selaku pihak yang berwenang dalam penegakan Peraturan Daerah Kabupaten Bungo Nomor 6 Tahun 2015 Tentang Pengelolaan Sampah. 


\section{DAFTAR PUSTAKA}

\section{Buku}

Abdurrahman, Maman dan Sambas Ali Muhidin. 2011. Panduan Praktis Memahami Penelitian, Bandung : Pustaka Setia.

Agustino, Leo. 2016. Dasar-dasar Kebijakan Publik. Bandung : Alfabeta.

Apriadji, Wied Harry. 2005. Memproses Sampah. Jakarta : Penebar Swadaya.

BPS Kabupaten Bungo, Kabupaten Bungo Dalam Angka 2018, Muara Bungo : BPS Kabupaten bungo

Narbuko, Cholid dan Abu Achmadi. 2016. Metode Penelitian. Jakarta : Bumi Aksara.

Purnawati, Endang. 2007. Sampah Jadi Uang. Klaten : Saka Mitra Kompentensi.

Raco, J.R. 2010. Metode Penelitian Kualitatif Jenis, karakteristik, dan Keunggulan. Jakarta : Gramedia Widiasarana Indonesia.

Satori, Djam'an dan Aan Komariah. 2013. Metode Penelitian Kualitatif. Bandung : Alfabeta.

Sugiyono. 2017. Metodologi Penelitian Administrasi dilengkapi Metode $R \& D$, Bandung : Alfabeta.

Suryati, Teti. 2009. Bijak \& Cerdas Mengelola Sampah Membuat Kompos dari Sampah Rumah Tangga. Jakarta : Agromedia Pustaka.

Tahir, Arifin. 2015. Kebijakan Publik \& Tranparansi Penyelenggaraan Pemerintah Daerah. Bandung : Alfabeta.

Winarno, Budi. 2014. Kebijakan Publik Teori, Proses dan Studi Kasus. Yogyakata : Caps.

Jurnal

Anggraini, Zepa dan Joko Susanto. 2019. Manajemen Persampahan di Kecamatan Rimbo Tengah Kabupaten Bungo, Tranparansi Jurnal Ilmiah Ilmu Administrasi Vol. 2 No. 2.

Ramdhiani, Tri Nanda. 2013. Implementasi Peraturan Daerah Nomor 02 Tahun 2011 Tentang Pengelolaan Sampah di Kelurahan Karang Anyar Kecamatan Sungai Kunjang Kota Samarinda, Ejournal Administrasi Negara, Vol. 1 No. 2.

\section{Peraturan Perundang-Undangan}

Undang-Undang Nomor 18 Tahun 2008 Tentang Pengelolaan Sampah.

Undang-Undang Nomor 12 Tahun 2011 Tentang Pembentukan Peraturan Perundang-undangan.

Peraturan Daerah Kabupaten Bungo Nomor 6 Tahun 2015 Tentang Pengelolaan Sampah. 